\title{
Regionalisme dan Kompleksitas Laut China Selatan
}

\author{
Ali Maksum* \\ ali.maksum@fisipol.umy.ac.id
}

\begin{abstract}
Abstrak
Hubungan antara regionalisme dan kompleksitas Laut China Selatan (LCS) jelas penting untuk diteliti lebih lanjut. Hal ini karena dampak dari sengketa LCS jelas berpengaruh terhadap stabilitas politik dan keamanan di Asia Tenggara. Tujuan utama artikel ini adalah untuk memahami konflik, latar belakang dan dampak dari sengketa LCS di negara-negara kawasan tersebut. Artikel ini dibagi menjadi enam bagian yaitu regionalisme dan LCS, sejarah konflik LCS, profil negara pengklaim, regionalisme dan solusi perdamaian, LCS dan keamanan regional dan kesimpulan. Penelitian ini juga dilengkapi dengan beberapa visualisasi untuk mengajak pembaca dalam sebuah imajinasi mendalam tentang LCS. Penulis menyimpulkan bahwa regionalisme Asia Tenggara menghadapi tantangan serius di tengah ancaman China yang berhasil mengambil keuntungan dari lemahnya multilateral ASEAN terkait masalah tersebut.
\end{abstract}

Kata kunci: Keamanan, konflik, Laut China Selatan, regionalisme

\begin{abstract}
The relationship between regionalism and the complexity of the South China Sea (SCS) issues is obviously critical to be examined. This is because the impact of the SCS disputes are clearly influence to the political and security stability in Southeast Asia. The primary objective of this article is to understand the conflicts, background and impact of the SCS disputes on the regional member states. This article is divided into six sections namely regionalism and the SCS, history of SCS conflicts, profile of claimant states, regionalism and peace solutions, SCS and regional security and conclusion. This study is also supplemented by some visualizations to engage the readers in deep imagination on the SCS. The author concludes that Southeast Asian regionalism was facing serious challenges vis-à-vis China which successfully took benefit from the ASEAN's weak multilateral approach on this issue.
\end{abstract}

Keywords: conflict, security, South China Sea, regionalism

\section{Pendahuluan: Regionalisme dan Laut China Selatan}

Salah satu definisi regionalisme adalah adanya interaksi atau hubungan baik orang, LSM, media, barang, finansial termasuk di dalamnya hubungan politik dan kerjasama militer di sebuah kawasan (Solongen, 2010). Regionalisme juga bisa dimaknai sebagai hubungan antar negara atau kelompok kepentingan yang terlembaga dengan baik dalam sebuah kawasan untuk mencapai tujuan tertentu (Anwar, 1996). Apa yang dimaksud dengan tujuan khusus tersebut di antaranya termasuk mempromosikan integrasi kawasan di mana dalam implementasinya seringkali negara

\footnotetext{
* Korespondensi: Prodi Hubungan Internasional, Universitas Muhammadiyah Yogyakarta, Jl. Lingkar Selatan, Tamantirto, Kasihan, Bantul, Yogyakarta 55183 Indonesia.
} 
memainkan peran dominan dan diwujudkan melalui organisasi tertentu serta bergerak dalam bidang spesifik (Santos, 2008). Definisi di atas mengindikasikan bahwa aspek kerja sama regional sangat luas mencakup berbagai bidang misalnya ekonomi, sosial, politik dan keamanan. Oleh karena itu, konsep multilateralisme yang dirangkai dalam sebuah organisasi regional sangat penting untuk mengintegrasikan dan meningkatkan kerja sama antar negara di sebuah kawasan (Weiss, 2010).

Dalam konteks Asia Tenggara, perbincangan tentang regionalisme tidak bisa lepas dari organisasi antara negara-negara Asia Tenggara atau Association of Southeast Asian Nations (ASEAN). Adanya ASEAN tidak dipungkiri menjadikan proses regionalisasi Asia Tenggara berlangsung dengan lebih mudah dan cepat. Implementasi Masyarakat Ekonomi ASEAN (MEA) atau ASEAN Economic Community tahun 2015 adalah bukti bahwa masyarakat Asia Tenggara dengan berbagai kekurangan dan kelebihan ingin membuka diri untuk saling berinteraksi dan bekerja sama dalam berbagai aspek mulai politik, ekonomi maupun sosial (Azhari Karim, 2013). Meskipun regionalisme Asia Tenggara berjalan dengan baik, namun bangunan regionalismenya tidak lepas dari campur tangan kekuatan luar yang "menginginkan" stabilitas politik kawasan. Dengan kata lain, unsur-unsur politik dari luar Asia Tenggara memainkan peran penting terutama era Perang Dingin di mana ASEAN didirikan juga tidak lain atas bangunan persaingan politik komunis-kapitalis. Artinya, orientasi politik dalam visi organisasi ASEAN sangat dominan dibanding faktor lain misalnya ekonomi (Anwar, 1996).

Disebabkan alasan politik tersebut, mau tidak mau konsep-konsep yang terkait politik termasuk aktor politik luar Asia Tenggara harus menjadi perbincangan. Dalam hal ini keterkaitan antara negara-negara ASEAN dengan kekuatan utama Perang Dingin terutama AS menjadi bagian yang tidak terpisahkan dalam setiap pembahasan. Oleh karena itu, muncullah apa yang dikenal dengan aliansi. Aliansi sendiri merupakan bagian strategi penting pertahanan negara dan kawasan untuk meningkatkan jaminan keamanan dan menjaga dari segala bentuk ancaman baik dari dalam maupun luar (Duffield, Michota, \& Miller, 2008). Maka ada dua pilihan politik yang bisa dilakukan sebuah negara yaitu (1) melakukan keseimbangan (balancing) atau (2) bergabung dengan kekuatan yang lebih dominan (bandwagoning) (Walt, 1985). Namun, kecenderungannya adalah sebuah negara secara pragmatis akan selalu bergabung dengan kekuatan lebih 
yang besar dibanding berhadapan secara "head-to-bead" dengan resiko sangat besar (Walt, 1985:6). Namun, pasca Perang Dingin seiring dengan terbukanya situasi politik internasional, ada pilihan lain yaitu melakukan keseimbangan dengan skala rendah (lowlevel balancing) (Roy, 2005). Salah satu penyebabnya ialah keterlibatan kekuatan besar terutama AS pasca Perang Dingin agak berkurang namun masih intensif dengan skala lebih kecil (Mauzy \& Job, 2007).

Salah satu pilar kekuatan integrasi kawasan Asia Tenggara adalah adanya norma atau nilai-nilai yang menjadi ciri khas ASEAN yaitu ASEAN Way. Dengan segala keterbatasan dan kelebihan yang dimiliki norma ASEAN, stabilitas Asia Tenggara merupakan bukti bahwa norma tersebut berkontribusi positif. Karena pada dasarnya ASEAN Way adalah konsep lingkungan sosial yang menekankan efek keakraban, konsensus, konsultasi, non-intervensi dan sebisa mungkin menghindari konflik dan masalah (Johnston, 2003). Dengan deskripsi yang lebih praktis Acharya (1998)mendeskripsikan ASEAN Way sebagai realisasi dari (1) hubungan interpersonal para pemimpin ASEAN; (2) ekspresi persamaan budaya; (3) norma-norma yang diakui dan disetujui serta disepakati dengan kesadaran tinggi untuk menjaga ASEAN. Kekhasan ASEAN dibanding dengan Uni Eropa (EU) misalnya diibaratkan sebagai budaya "kampung" yang senantiasa melekat dalam setiap proses diplomasi negara ASEAN (Acharya, 1998:56).

Dalam konteks LCS, tampaknya ASEAN Way memunculkan dilema tatkala China yang masuk harus berbenturan dengan norma tersebut. Konsensus antar anggota ASEAN mungkin bisa dikonsolidasikan dengan baik, namun permasalahan LCS sangat kompleks. Elemen kedaulatan dan perebutan sumber daya alam menjadi isu panas yang setiap saat bisa muncul menjadi sebuah konflik kawasan. Justru dalam konteks LCS, nilai-nilai ASEAN Way terkooptasi oleh kepentingan China yang masuk secara "bilateral" tanpa melalui saluran ASEAN yang selama ini memang tidak terkonsolidasi dengan baik. Realitasnya, dalam menghadapi isu-isu yang melibatkan kepentingan nasional, ASEAN lebih banyak menggunakan diplomasi bilateral dibanding multilateral (Acharya, 1998:68). Sehingga negara ASEAN harus bekerja keras dan berfikir lebih mendalam agar permasalahan LCS bisa diurus dengan baik. Konsep regionalisme dalam hal ini jelas menghadapi tantangan berat dan memerlukan 
sebuah kerja keras antar negara Asia Tenggara untuk menghadapi kompleksitas LCS yang tidak mudah.

\section{Sejarah Konflik Laut China Selatan}

Latar belakang konflik LCS bisa dikatakan sudah ada sejak lama dengan bentuk, kondisi dan dinamika politik global yang berbeda-beda. Berikut adalah peta negaranegara yang terlibat langsung klaim di LCS sekaligus untuk memahami posisi geografis LCS.

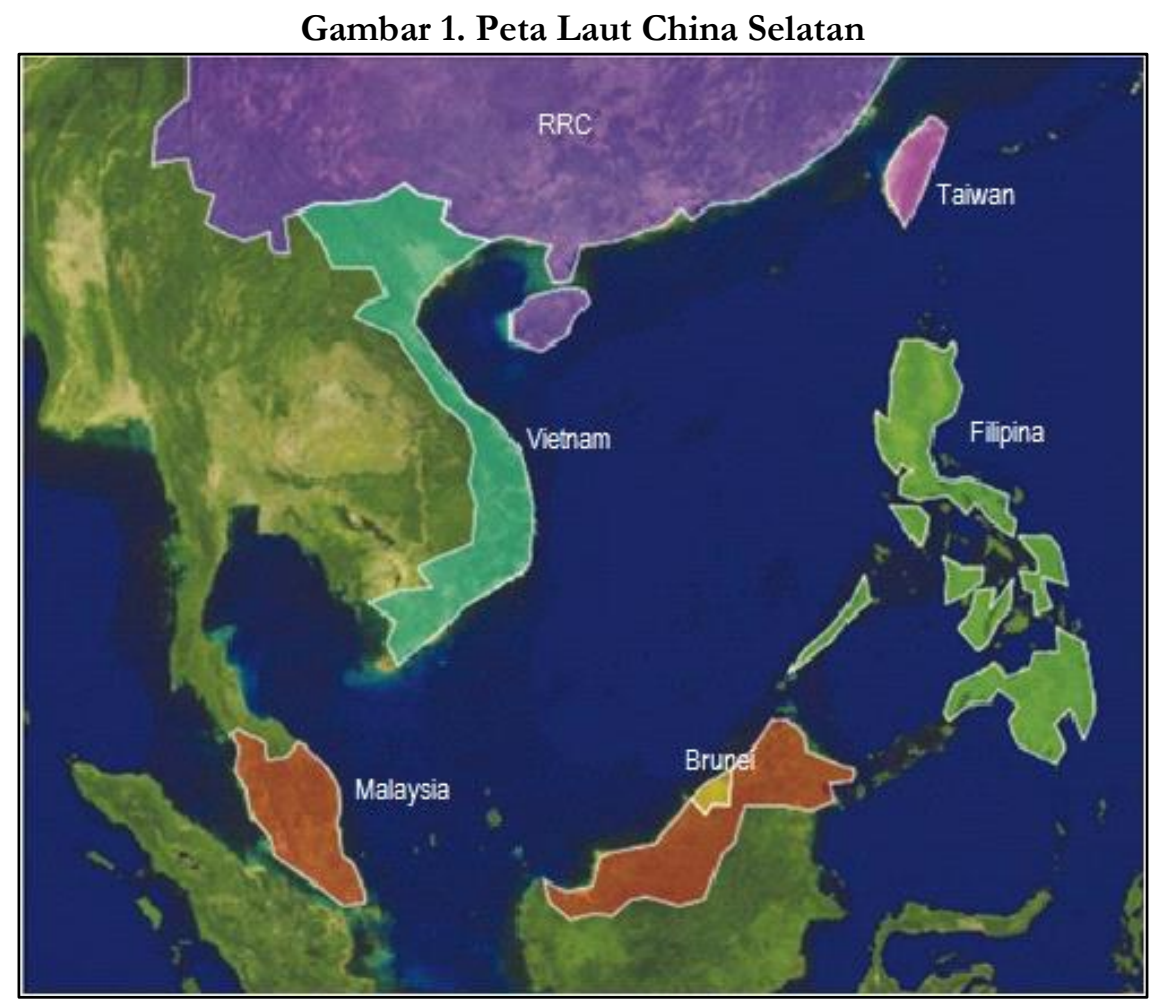

Sumber: Poling (2013)

Dalam sejarahnya, konflik LCS sudah ada sejak lama jauh sebelum adanya negara-bangsa (nation state) di kawasan Asia Tenggara. Bahkan kerajaan lokal ketika itu tampak sudah memetakan dan melihat potensi besar di LCS. Sehingga muncul secara bertahap dorongan politik dari entitas tersebut untuk menguasasi kawasan LCS yang ketika itu sudah ramai dengan kapal-kapal dagang. Dinasti Han misalnya termasuk salah satu poros perdagangan yang melihat potensi tersebut terutama jalur pelayaran barang dan jasa. Intensitas Dinasti Han, tampaknya juga memicu aktor-aktor lokal di 
sekitar LCS untuk terlibat aktif dalam perebutan sumber daya dan potensi LCS. Misalnya Kerajaan Funan, Kerajaan Angkor, Kerajaan Sriwijaya, Kerajaan Ayutthaya, Kerajaan Champa dan Kesultanan Melaka (Tonnesson, 2001).

Dalam perjalanannya, aktor-aktor lokal tersebut silih berganti mengendalikan LCS untuk mengambil keuntungan sebesar-besarnya dari tingginya arus perdagangan yang melewati kawasan tersebut. Pada abad ke-8 hingga abad ke-12, kerajaan-kerajaan tersebut mengontrol penuh LCS dan kawasan lain disekitarnya. Namun, sejak abad ke-12 hingga ke 15, armada-armada China yang dikomandoi oleh Laksamana Cheng Ho mendominasi LCS. Laksamana Cheng Ho yang seorang Muslim, pada akhirnya ikut menyemarakkan syi'ar agama Islam di Nusantara dan sekitarnya. Situasi mulai berubah ketika saudagar-saudagar Barat mulai berdatangan seperti dari Portugis, Spanyol, Belanda, Inggris, Perancis didukung dengan kemampuan militer semakin dominan di LCS yang sebelumnya dikuasai saudagar Arab. Pada abad ke-17, Belanda terlihat paling dominan di kawasan LCS. Memasuki abad ke-18 dan ke19 dominasi pejajah Eropa tampaknya semakin menurun. Namun Inggris dan Perancis masih bertahan di LCS hingga akhirnya beberapa negara jajahannya mendapatkan kemerdekaan (Tonnesson, 2001).

Untuk memahami konflik LCS tentu harus juga memahami inti masalah dan persoalan pokoknya. Selain potensi, hal yang paling fundamental dalam isu LCS adalah masalah kedaulatan negara. Terjadinya apa yang disebut sebagai tumpang tindih garis wilayah perbatasan yang diklaim oleh negara-negara terlibat terhadap pulau-pulau di LCS adalah intisari isu LCS.Sedangkan jika ditelusuri lebih jauh, rumitnya masalah LCS tidak lain adalah kegagalan perjanjian San Francisco Treaty tahun 1951 dalam menetapkan status Kepulauan Spratly pasca kekalahan Jepang pada Perang Dunia II (Jones \& Smith, 2015). Menurut U.S. Energy Information Administration (EIA) potensi sumber daya alam di LCS sangat besar. Diperkirakan LCS mempunyai kandungan minyak sekitar 11 milyar barel dan juga kaya akan gas alam mencapai 190 trilyun kaki kubik (Tfc) serta cadangan hidrokarbon yang sangat penting sebagai pasokan energi. Terkait dua pulau utama yang menjadi sengketa yaitu Kepulauan Spratly (Spratly Islands) dan Kepulauan Paracel (Paracel Islands) diduga kuat mengandung cadangan mineral misalnya 2,5 milyar barel dan25,5 Tcf gas alam yang belum digarap (U.S. Energy Information Administration, 2013). Sedangkan pemerintah China 
mengklaim bahwa LCS mempunyai potensi minyak sebesar 17 milyar ton. Jumlah ini lebih besar daripada potensi minyak Kuwait yang hanya mencapai 13 milyar ton (Ma, 2006).

Potensi sumber daya alam yang sedemikian besar sudah pasti memicu persaingan negara-negara di LCS untuk menguasai wilayah tersebut. Sebagian besar negara di sekitar LCS mempunyai wilayah klaim dalam skala yang berbeda-beda. Kawasan LCS yang merupakan rangkaian pulau berjumlah lebih dari 30.000 pulau termasuk gugusan karang tidak hanya kaya akan potensi sumber daya alam, namun posisi strategis LCS juga menjadi incaran banyak negara untuk menggunakannya sebagai sistem pertahanan. Akibatnya, eskalasi konflik muncul menjadi ancaman serius di LCS. Secara spesifik, beberapa negara secara resmi mengklaim LCS. Misalnya Kepulauan Paracel diklaim oleh tiga negara yaitu China, Taiwan dan Vietnam. Sedangkan Kepualaun Spratly menjadi rebutan antara China, Taiwan, Malaysia, Filipina, Vietnam dan Brunei Darussalam. Berdekatan dengan Kepulauan Spratly terdapat gugusan karang yang menjadi sengketa antara Filipina, China dan Taiwan yang dikenal dengan Scarborough Shoal. Sumber utama konflik LCS tidak lain terkait terkait kawasan "nine-dash line” adalah yang paling memicu ketegangan kawasan termasuk melibatkan Amerika Serikat (AS) kecuali Singapura (Lunn, 2016). Klaim China di wilayah “nine-dash line”bisa digambarkan dalam peta berikut (lihat Gambar 2).

Adanya berbagai klaim tersebut bisa dipastikan berdampak pada eskalasi konflik dalam skala yang lebih besar. Bahkan timbul banyak ketegangan yang bersumber dari aktivitas saling klaim di LCS. Dalam konteks ini, posisi AS sangat menarik. Selain sebagai pesaing berat China di LCS, AS ternyata sangat berkepentingan dengan kawasan tersebut. AS pada dasarnya mempunyai dua kepentingan utama yaitu akses pelayaran dan stabilitas politik-keamanan LCS. Bagi AS sangat penting untuk bisa secara leluasa menggunakan akses pelayaran LCS. Selain itu, menjaga stabilitas LCS berarti juga menjaga stabilitas Asia Tenggara yang sangat penting bagi AS (Fravel, 2012). Menurut pandangan Sekretaris Negara AS Hillary Clinton, AS memiliki "kepentingan nasional" di LCS dan mengharapkan semua negara termasuk China menghormati hukum internasional. Padahal, AS sendiri menolak untuk meratifikasi hukum laut internasional atau United Nations Convention on the Law of the Sea (UNCLOS) (Yujuico, 2015). 
Gambar 2. Nine Dash Line di Laut China Selatan

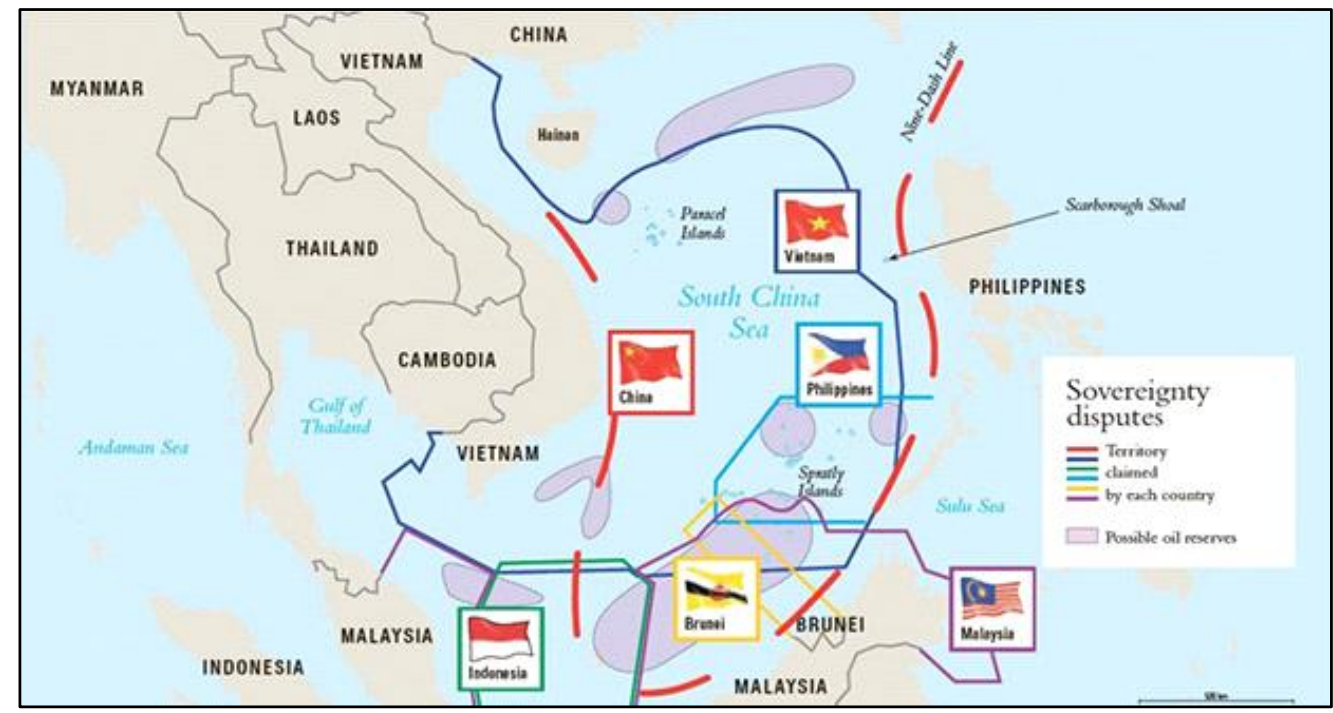

Sumber: Gupta (2015)

Analisis di atas menunjukkan bahwa konflik LCS sangat rumit dan kompleks. Potensi sumber daya alam terutama minyak dan gas serta posisi strategis sebagai alur perdagangan internasional tampaknya menjadi pemicu utama konflik LCS. Sikap kukuh China di LCS tentu semakin mengkhawatirkan semua pihak seiring dengan meningkatnya aktivitas baik ekonomi maupun militer di kawasan tersebut. Misalnya, pada Juni 2012, perusahaan minyak China atau China National Offshore Oil Corporation (CNOOC Limited) melakukan eksplorasi dan memberikan konsesi kepada perusahaan asing di sembilan titik di LCS. Padahal kawasan tersebut sangat dekat dengan bibir pantai Vietnam dan justru berjarak sangat jaut yaitu kurang lebih 230 Mil laut dari China (Poling, 2013). Tentu saja tindakan tersebut langsung memicu ketegangan antar kedua negara bahkan bisa mengancam stabilitas keamanan Asia Tenggara dan sekitarnya.

\section{Profil Negara-Negara Yang Terlibat Konflik di Laut China Selatan}

Negara-negara yang terlibat langsung sengketa LCS ada enam negara yaitu Brunei Darussalam, China, Malaysia, Filipina, Taiwan dan Vietnam. Masing-masing negara mempunyai dasar dan pandangan yang berbeda-beda tentang klaim mereka di LCS. Berikut profil negara-negara tersebut. 


\section{Brunei Darussalam}

Sampai tahun 2011, Brunei Darussalam secara aktif telah melakukan eksplorasi minyak di LCS. Hal ini bisa dilakukan tidak lain disebabkan sengketa wilayah dengan Malaysia tahun 2009 bisa diselesaikan yang berdampak pada leluasanya kegiatan eksplorasi Brunei Darussalam di LCS. Namun, aktivitas Brunei Darussalam mulai terkendala ketika secara langsung bersinggungan dan terlibat sengketa di LCS. Padahal, Brunei tidak melakukan klaim apapun sebelumnya atas wilayah di LCS terutama Kepulauan Spratly dan Kepulauan Paracel. Tetapi, pasca memperoleh kemerdekaan dari Inggris pada tahun 1985, Brunei Darussalam secara tidak langsung bersengketa dengan Vietnam sebagai akibat dari meluasnya garis landasan kontinen warisan penjajah Inggris berdasarkan undang-undang 1958 U.K. Order in Council. Akibatnya, Brunei merasa berhak atas status kawasan Louisa Reef yang merupakan bagian dari Kepulauan Spratly. Sudah tentu klaim Brunei Darussalam ditolak semua negara pengklaim LCS yaitu China, Taiwan, Malaysia, Vietnam dan Filipina (U.S. Energy Information Administration, 2013).

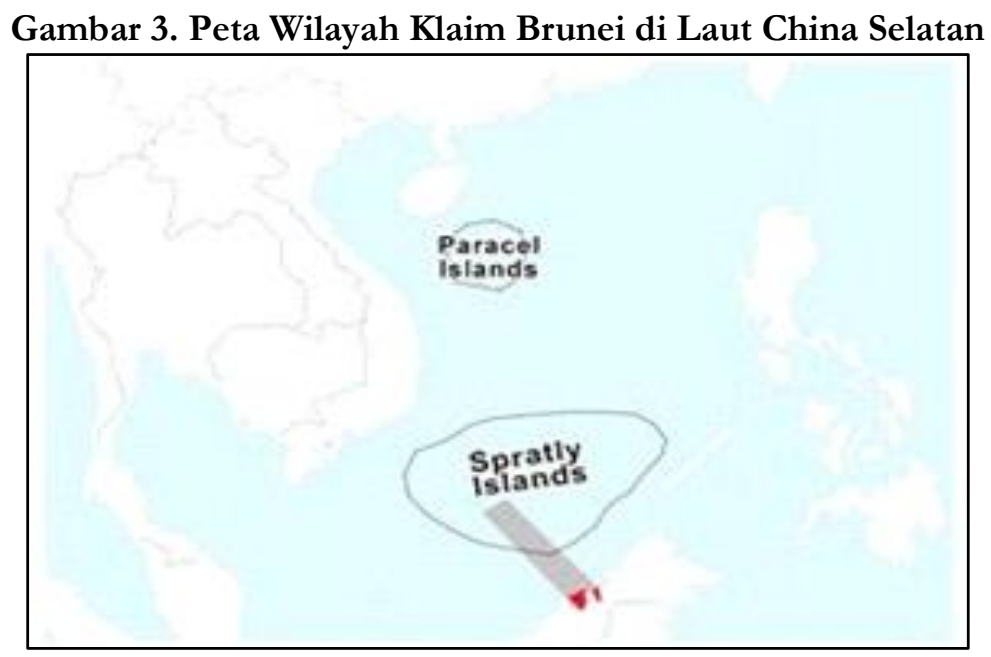

Sumber: U.S. Energy Information Administration (2013)

Klaim Brunei atas status Louisa Reef menjadi sumber masalah terutama dengan China, Vietnam dan Malaysia. Namun pasca penandatanganan Exchange of Letters antara Malaysia-Brunei tahun 2009, klaim Malaysia atas Louisa Reef dengan sendirinya batal. Louisa Reef yang terletak di 6²0'7"N 113²16'47"E kurang lebih 120 mil barat daya garis pantai Brunei dan 408 mil dari garis pantai Vietnam. China 
menamakan Louisa Reef sebagai Nantong Jiao (南通), sementara dalam istilah Melayu Louisa Reefdisebut Terumbu Semarang Barat Kecil. Rumitnya masalah klaim Louisa Reef oleh Brunei dan negara-negara terkait tampaknya juga bersumber dari kurang jelasnya penggambaran Louisa Reef karena ada yang mengklaim hanya "gugusan karang" dan ada yang menyebutnya "pulau." Perbedaan pendefinisian tersebut pada akhirnya berimbas kepada masalah perbatasan termasuk Brunei Darussalam di kawasan rawan konflik LCS (Roach, 2014).

\section{China}

China adalah antara negara paling penting dalam konflik di LCS. Kawasan klaimnya yang sangat luas hingga mencapai seluruh wilayah LCS menjadi pemicu ketegangan dengan negara-negara di sekitarnya. Untuk lebih jelasnya bisa dilihat dalam visualisasi di bawah berikut.

\section{Gambar 4. Peta Wilayah Klaim China di Laut China Selatan}

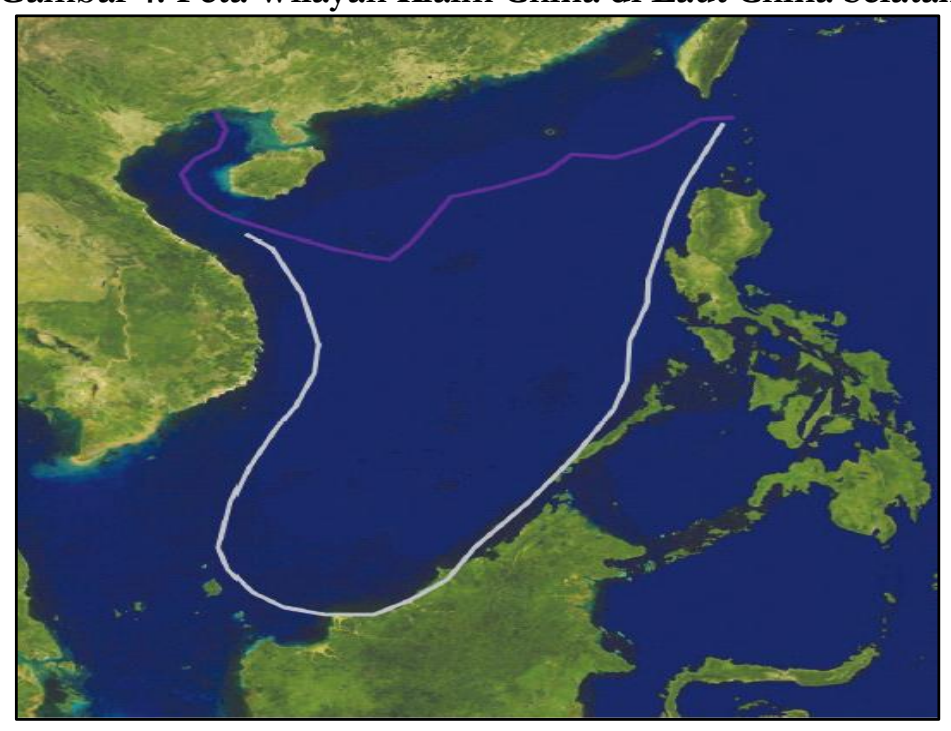

Sumber: Poling (2013)

Sebagaimana telah dibahas sebelumya, klaim China pada dasarnya terdefinisikan dalam "nine-dash line" sebuah kawasan yang sangat luas membentang beratus-ratus mil dari selatan hingga ke kawasan timur Provinsi Hainan, China. Artinya, jika sampai timur Provinsi Hainan, Taiwan dan China mempunyai kawasan klaim yang sama. Isu klaim di LCS jelas menjadikan perseteruan kedua negara semakin panas. 
Bersama-sama dengan Vietnam, kedua negara China dan Taiwan juga sama-sama menggunakan dalil sejarah dalam melakukan klaimnya (Lunn, 2016).

Seiring dengan berjalannya waktu, China semakin agresif di LCS dengan melakukan eksplorasi sumber daya alam. Melalui tiga perusahaan minyak negara China melakukan eksplorasi besar-besaran. Ketiga perusahaan tersebut adalah China National Offshore Oil Corporation (CNOOC), China Petroleum \& Chemical Corporation (Sinopec) dan China National Petroleum Corporation (CNPC) (U.S. Energy Information Administration, 2013). Menariknya, perhatian serius AS terkait ketegangan di LCS yang melibatkan China menjadikan eskalasi konflik semakin meningkat. Walaupun dikatakan bahwa sikap China semakin moderat terutama pasca pernyataan Sekretaris Negara AS Hillary Clinton pada ASEAN Regional Forum (ARF) Juli 2010 (Fravel, 2012). Namun, realitasnya ketegangan semakin meningkat terutama antara China dan negara ASEAN (Lunn, 2016). Selain itu, tentu saja berpengaruh kepada arah kebijakan luar negeri AS di ASEAN terkait LCS yang mempunyai potensi perdagangan mencapai 5,3 trilyun USD (Council on Foreign Relations, 2016).

3. Malaysia

Ketertarikan Malaysia yang terlibat dalam konflik di LCS juga tidak lepas dari perebutan sumber daya alam. Perusahaan minyak Malaysia PETRONAS secara aktif juga meningkatkan kegiatan eksplorasinya di LCS dengan menggandeng perusahaan multinasional lainnya misalnya Lundin, BHP Billiton, ConocoPhillips, ExxonMobil, Hess, KUFPEC, MDC O\&G, Murphy Oil, Newfield, Nippon, Petrofac, Roc Oil, Shell, dan Talisman Energy (U.S. Energy Information Administration, 2013). Dengan menggunakan bukti sejarah warisan penjajah Inggris, klaim Malaysia adalah (1) sejauh 12 mil laut, termasuk (2) Zona Ekonomi Ekslusif (ZEE) yang berdampak pada (3) perluasan luas landasan kontinen hingga ke LCS. Malaysia sendiri telah menandatangani konvensi hukum laut internasional (UNCLOS) pada 2 Desember 1982 dan meratifikasinya pada 14 Oktober 1996 (Roach, 2014). Adapun visualisasi klaim Malaysia di LCS dapat dilihat dalam Gambar 5.

Keterlibatan Malaysia dalam konflik di LCS dimulai pasca penerbitan Peta Baru Menunjukekan Sempadan Perairan dan Pelantar Benua Malaysia (selanjutnya disingkat: Peta Baru) pada tanggal 21 Desember 1979 dan secara resmi mengklaim perluasan ZEE pada tanggal 25 April 1980. Dampaknya, Malaysia secara tidak langsung terlibat 
sengketa dengan negara tetangga terkait klaim beberapa wilayah. Misalnya (1) Pulau Sipadan-Ligitan dengan Indonesia, (2) Pulau Batu Puteh dengan Singapura, (3) Limbang, Lawas, Terusan, Rangau dan Louisa Reefdengan Brunei, dan (4) dengan Filipina, Vietnam, China dan Taiwan terkait Kepulauan Spratly di LCS (Salleh, Che Mohd Razali, \& Jusoff, 2009). Penerbitan Peta Barmoleh pemerintah Malaysia langsung memicu ketegangan dengan Indonesia dan bahkan ditentang oleh delapan negara lain di LCS yang berimplikasi kepada memanasnya kawasan tersebut (Salleh, 2007).

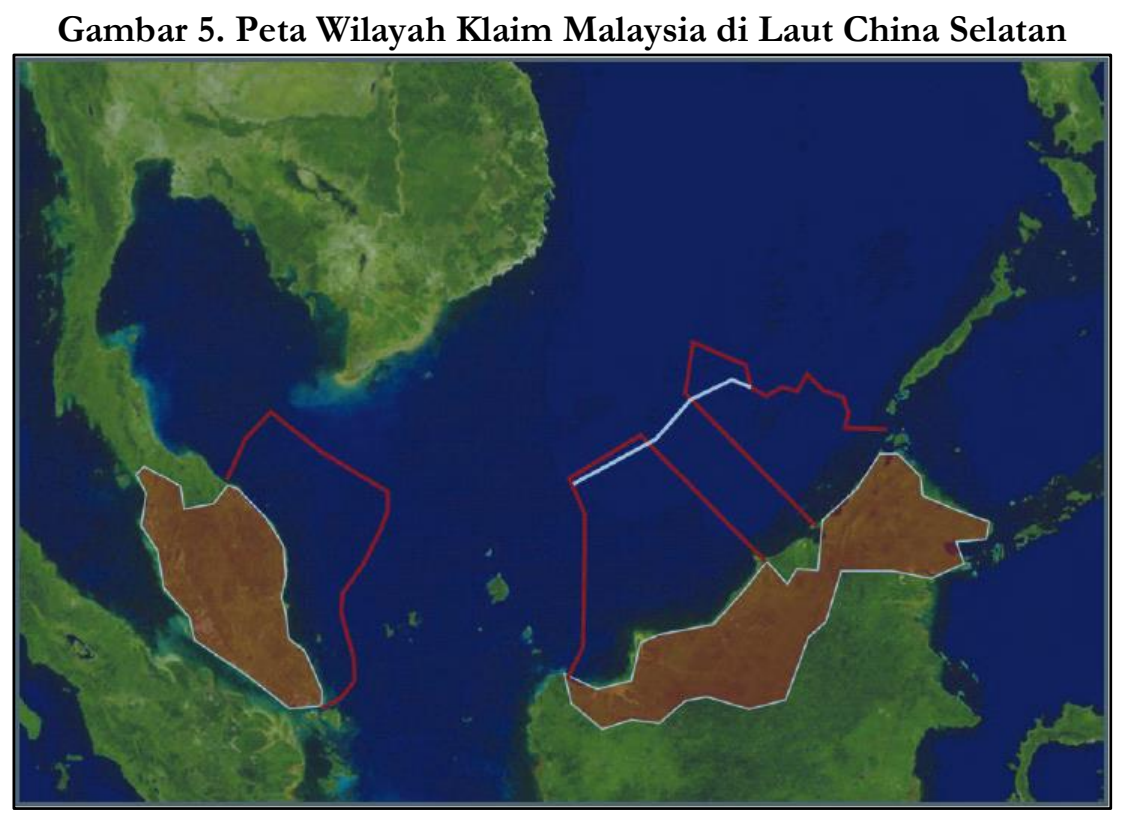

Sumber:Poling (2013)

\section{Filipina}

Filipina menjadi salah satu negara yang penting dalam konflik LCS. Selain itu, Filipina termasuk menjadi negara yang paling awal melakukan aktivitas strategis di LCS. Pada tahun 1970-an, Filipina telah mulai melakukan eksplorasi di kawasan Reed Bank yang merupakan bagian Kepulauan Spratly. Usaha keras Filipina membuahkan hasil dengan ditemukannya sumber gas alam pada tahun 1976 di kawasan tersebut. Tindakan Filipina langsung diprotes China dan mendesak Manila untuk segera menghentikankegiatannya di LCS (U.S. Energy Information Administration, 2013). Namun, keadaan justru semakin memanas karena Presiden Ferdinand Marcos mengeluarkan Dekrit Presiden pada tanggal 11 Juni 1978 yang memasukkan 
Kepulauan Spratly yang mereka kenal sebagai Kelompok Kepulauan Kalayaan ke dalam wilayah teritorial Filipina (Presidential Decree no. 1596, 1978). Untuk lebih jelas tentang wilayah klaim Filipina di LCS dapat dilihat dalam visualisasi Gambar 6.

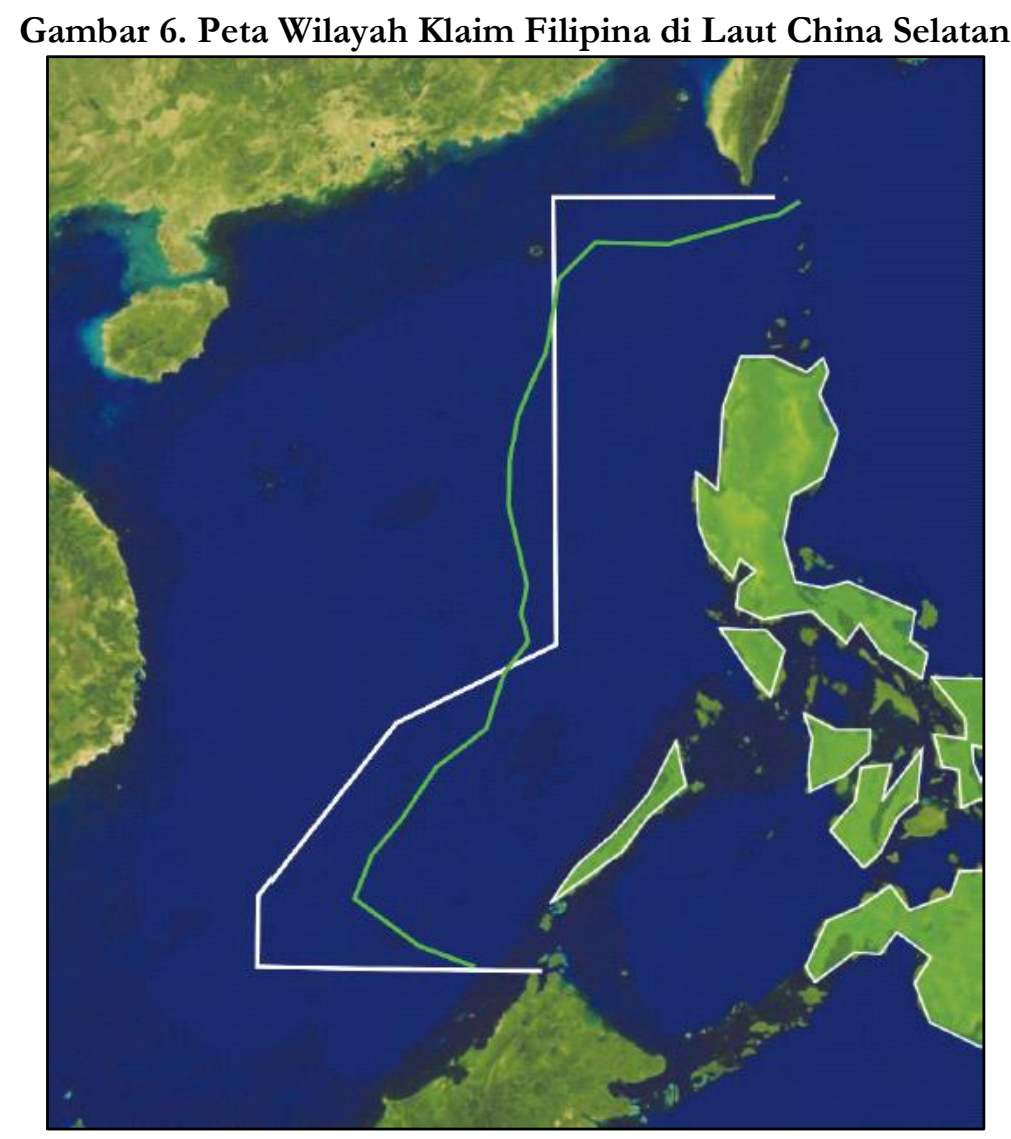

Sumber:Poling (2013)

Pada tahun 2013, Filipina melayangkan gugatan atas klaim China di LCS ke Mahkamah Internasional (ICJ) di Belanda melalui peradilan UNCLOS. Namun sekali lagi Beijing mengingatkan Manila untuk tidak terlalu agresif dalam permasalahan LCS yang melibatkan kedua negara. Karena bagi China hal tersebut bisa merusak persahabatan yang selama ini sudah terjalin dengan baik (Weatherbee, 2009:148). Bagi Filipina, kebijakan China di LCS sangat mengancam Filipina. Sebaliknya, Filipina tidak terlalu mempermasalahkan Vietnam yang juga melakukan aktivitas strategis di LCS. Filipina beralasan bahwa aktivitas Vietnam tidak mengancam karena dilakukan dalam skala kecil dibandingkan China yang melakukan pembangunan dengan skala besar. Namun, tidak dipungkiri bahwa sikap Filipina terhadap Vietnam yang sangat moderat 
juga dilatarbelakangi oleh kerja sama intensif bidang keamanan antara Manila dan Hanoi (Voice of America, 8/5/2015).

\section{Taiwan}

Posisi Taiwan dalam konflik LCS bisa dikatakan menarik. Karena kawasan klaim Taiwan di LCS tidak lain adalah wilayah klaim China itu sendiri (Ma, 2006). Persamaan sejarah politik membuat Taiwan merasa mempunyai hak yang sama atas wilayah LCS. Sedangkan China masih menganggap Taiwan sebagai salah satu provinsinya. Dalil klaim Taiwan adalah berdasarkan sejarah negara tersebut terutama pasca pemisahan diri dari China yang dipimpin oleh Chiang Kai-shek. Pada tahun 1947 pemerintah Kuomintang membuat peta resmi yang memasukkan wilayah-wilayah klaim termasuk seluruh kawasan LCS misalnya Kepulauan Spratly, Kepulauan Paracel, Pulau Pratas dan Scarborough Reef dalam teritorial Taiwan(U.S. Energy Information Administration, 2013). Tentang penggambaran wilayah klaim Taiwan di LCS dapat dilihat dalam visualisasi Gambar 7.

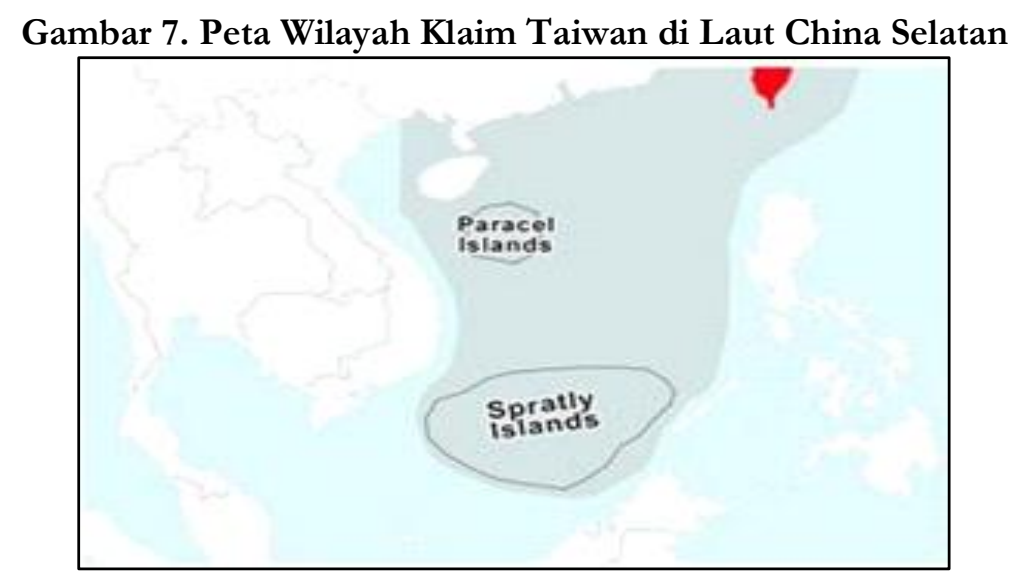

Sumber: U.S. Energy Information Administration (2013)

Dalam konteks klaim Taiwan di LCS, Taiwan terfokus pada sebuah pulau yang dikenal dengan Pulau Itu Aba yang merupakan pulau terbesar di Kepulauan Spratly (Boston Global Forum, 2015; Gewirtz, 2016; Lunn, 2016). Konsekensinya, garis ZEE Taiwan semakin luas bahkan menjangkau pulau-pulau sekitar LCS. Pulau Natuna misalnya, walaupun sudah resmi dan diakui oleh Indonesia sebagai bagian teritorialnya, namun Taiwan dan juga China yang sama-sama mengklaim seluruh kawasan LCS menganggap Natuna adalah bagian dari wilayah mereka (Ma, 2006, p. 5). 
Indonesia juga pada dasarnya tidak terlibat langsung dengan konflik LCS. Meskipun demikian, tindakan China dan Taiwan yang mengklaim Pulau Natuna menjadi perhatian serius pemerintah Indonesia. Indonesia sudah pasti tidak mau tinggal diam dan tegas dengan isu kedaulatan negara. Sebagai langkah nyata, pemerintah Indonesia misalnya melalui TNI-AL membakar dan menenggelamkan kapal nelayan China yang masuk wilayah Indonesia di LSC pada bulan Juni 2016 (Council on Foreign Relations, 2016).

\section{Vietnam}

Klaim Vietnam di LCS juga didasari oleh bukti sejarah penjajah sebelumnya yaitu Prancis. Ketika menguasasi Vietnam, pemerintah kolonial Prancis melakukan beberapa ekspedisi ke LCS termasuk Kepulauan Spratly dan Kepulauan Paracel. Pada awalnya ketika Vietnam terbelah menjadi Republik Demokratik Vietnam atau Vietnam Utara (di bawah Ho Chi Minh) dan The State of Vietnam atau Vietnam Selatan (di bawah Bao Dai) sikap Prancis berbeda. Ketika itu, Prancis yang mendukung Vietnam Selatan memasukkan Kepulauan Paracel dalam wilayah teritorialnya. Namun, Prancis menolak klaim Vietnam Selatan atas Kepulauan Spratly karena sudah diklaim Prancis. Menariknya, pasca Perang Dingin, terjadi persaingan sengit terutama antara Vietnam dan China untuk mendekati negara-negara ASEAN. Tujuanya jelas agar mendapat dukungan terkait klaim di LCS dan permasalahan tidak semakin rumit (Tonnesson, 2001). Untuk lebih jelas melihat gambaran tentang klaim Vietnam dapat dilihat dalam visualisasi Gambar 8.

Keterlibatan negara-negara di atas jelas berdampak kepada polarisasi politik regional Asia Tenggara. Bagi negara-negara yang terlibat langsung seperti Brunei Darussalam, China, Malaysia, Filipina, Taiwan dan Vietnam aspek kedaulatan dan menjaga kepentingan nasional menjadi fokus isu di LCS. Walaupun Indonesia tidak secara langsung terlibat di LCS, namun sewaktu-waktu bisa terseret masalah karena salah satu bagian wilayah terutama Pulau Natuna menjadi bagian klaim China dan Taiwan. Negara lain misalnya Thailand tidak berkepentingan di LCS meskipun Teluk Thailand posisinya tidak jauh dari LCS. Sedangkan Singapura, mempunyai posisi strategis sebagai mediator dan corong negara-negara Asia Tenggara terkait isu LCS. Adapun AS, posisinya sangat jelas yaitu mempunyai "kepentingan besar" di LCS terutama potensi ekonomi dan pertahanan keamanan. 


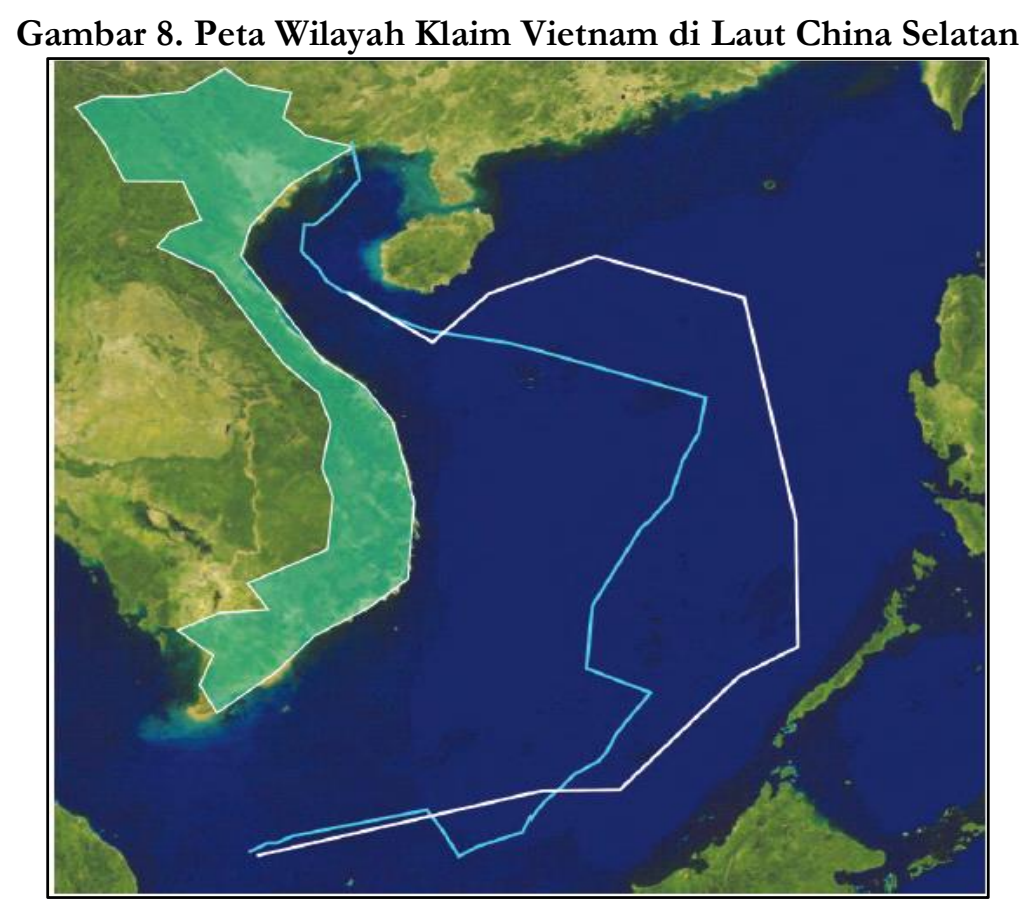

Sumber:Poling (2013)

\section{Regionalisme dan Solusi Damai di Laut China Selatan}

Tindakan saling klaim yang terjadi di LCS jelas sangat mempengaruhi situasi keamanan regional Asia Tenggara. Dalam konteks ini, ASEAN sebagai organisasi regional paling penting memainkan peran sentral agar stabilitas politik Asia Tenggara tetap terjaga. Peran ASEAN dalam hal ini bisa diwujudkan melalui pelaksanaan perundingan-perundingan untuk memediasi negara-negara yang terlibat. Salah satu peran penting tersebut telah dimainkan oleh Indonesia. Pada tahun 1990 Indonesia menginisiasi sebuah workshop untuk mencari jalan penyelesaikan konflik di LCS. Tema workshop tersebut adalah "Workshops on Managing Potential Conflict in the South China Sea.'Namun salah satu kendalanya adalah sentimen nasionalisme yang sangat tinggi terutama antar negara ASEAN. Dampaknya tentu saja proses dialog menjadi sangat lambat karena kuatnya kepentingan nasional. Sehingga seringkali menemui jalan buntu dan sulit untuk dilakukan kerja sama antar pihak terkait (Bateman, 2011).

Walau bagaimanapun, pandangan tersebut ditolak oleh Hasjim Djalal. Menurut pakar hukum laut tersebut, adanya workshop memiliki arti penting dalam 
menjaga konsistensi negara-negara ASEAN untuk mengutamakan jalur-jalur diplomasi damai. Bagi Hasjim Djalal workshop yang digagas Indonesia tahun 1990 dirancang untuk membincangkan isu-isu strategis LCS dengan harapan para peserta dapat leluasa berdialog tanpa sekat-sekat politik dan diplomasi. Sehingga, jalan damai dapat terbuka lebar di LCS. Sebaliknya, berbagai insiden kontak senjata dan ketegangan di LCS justru akan semakin memperburuk situasi di kawasan tersebut (Maritime Security Programme Conference Report, 2007).

Pasca diadakannya workshop tahun 1990 di Bandung, Indonesia, perkembangan LCS terus menunjukkan peningkatan signifikan. Tahun 1992 misalnya, para menteri luar negeri ASEAN sepakat untuk menandatangani Deklarasi Manila tentang LCS. Namun, China menerima hasil kesepakatan negara-negara ASEAN di Manila. Begitu juga dalam pertemuan pertama ASEAN Regional Forum (ARF) tahun 1994 di Bangkok, Thailand, China juga menolak hasil kesepakatan untuk menempuh jalur negosiasi multi-lateral. China cenderung memilih negosiasi langsung (diplomasi bilateral) dengan negara-negara terlibat. Sikap China masih konsisten termasuk pada pertemuan kedua ARF tahun 1995 walaupun sebelumnya akan melunak pasca insiden Mischief Reef yang melibatkan kontak fisik antara militer China dan Filipina. China akhirnya menandatangani kesepakatan ultilateral melalui Menteri Luar Negeri Wang Yi dalam Declaration on the Conduct of Parties in the South China Sea pada bulan November 2002 di Phnom Penh, Kamboja. Hal ini dilakukan China untuk menghindari ketegangan yang semakin meningkat di LCS (Emmers, 2005).

Dalam perkembangan terbaru, isu LCS menjadi topik yang hangat dalam dua agenda internasional penting tahun 2015. Pertama, pertemuan tingkat tinggi AsiaPacific Economic Cooperation (APEC) di Manila, Filipina dan kedua, pertemuan tingkat tinggi ASEAN atau ASEAN Summit di Kuala Lumpur, Malaysia. Pada pertemuan APEC, tidak menghasilkan kesepakatan apapun dan sikap China masih sama. Namun, mendapat respon menarik dari Presiden AS Barrack Obama dan Perdana Menteri Jepang Shinzo Abe yang menyatakan perlunya penegakan hukum internasional. Sedangkan dalam pertemuan ASEAN Summit, China dikatakan sukses memanfaatkan lemahnya kultur regionalisme ASEAN untuk memecah-belah sehingga bisa menjaga kepentingan nasional China (Lunn, 2016; Weatherbee, 2009). 
Beberapa pakar menawarkan pendapatnya tentang solusi ke depan dalam menyelesaikan konflik LCS. Misalnya kerja sama dalam bidang non-keamanan tradisional pengembangan sumber daya migas, manajemen perikanan, keamanan laut, penelitian ilmu kelautan dan konservasi lingkungan laut (Bateman, 2011). Selain itu, diperlukan juga penguatan Code of Conduct (COC) dengan melibatkan semua negara termasuk AS, Jepang dan bahkan India (Vu \& Phuong, 2014). Persatuan antar negaranegara ASEAN tampaknya sangat diperlukan untuk menghadapi agresifitas China yang semakin meningkat seiring dengan meningkatnya kekuatan ekonominya(Kung, 2015).Semua solusi tersebut tampaknya bermuara pada sebuah kesimpulan bahwa ketegangan di LCS yang menyeret AS dan China akan sangat merugikan ASEAN. Justru itu, di tengah kerja sama ekonomi yang semakin menguntungkan, diperlukan kerja sama kolektif yang padu antar negara ASEAN untuk menghadapi kekuatan Chinadalam menyelesaikan sengketa LCS (Muzaffar, 2012).

Upaya meredam konflik jelas sangat diperlukan mengingat potensi ekonomi dan perdagangan yang sangat besar di sekitar kawasan LCS. Hampir sebagian besar negara yang berkepentingan di LCS terlibat dalam kerja sama ekonomi dan perdagangan. Dalam Trans Pacific Partnership (TPP) misalnya beranggotakan Australia, Brunei, Canada, Chile, Jepang, Malaysia, Mexico, New Zealand, Peru, Singapura, AS dan Vietnam. Sedangkan kerja sama lain yaitu Regional Comprehensive Economic Partnership (RCEP) terdiri dari seluruh anggota ASEAN ditambah Australia, China, India, Jepang, Korea, New Zealand. Nilai perdagangannya juga sangat besar, misalnya ekspor ASEAN-China mencapai 1, 020 milyar USD. Selain itu, hampir $50 \%$ total pelayaran komersial dunia melewati perairan Indo-Pacific yang mengangkut kurang lebih 25\% dari seluruh pelayaran angkutan migas dunia (The Asia Maritime Transparency Initiative and The Center for Strategic and International Studies, 2014). Potensi tersebut tentu sangat menguntungkan dan timbulnya konflik hanya mendatangkan kerugian bagi semua pihak.

\section{Laut China Selatan dan Keamanan Regional}

LCS dan keamanan regional Asia Tenggara menjadi dua isu yang selalu muncul dalam setiap pembahasan mengenai topik tersebut. Hal ini tidak lain karena LCS mempunyai potensi konflik yang sangat tinggi dan tentunya akan berdampak 
kepada stabilitas di sekitarnya terutama Asia Tenggara. Dalam konteks LCS, China menjadi negara yang paling dominan dan juga termasuk negara yang sering terlibat ketegangan dengan negara-negara terkait. Sejak tahun 1974 hubungan China-Vietnam memanas pasca militer kedua negara terlibat indisen baku tembak di LCS terkait isu Kepulauan Spratly dan Kepulauan Paracel. Selain itu, China juga melakukan pengusiran dan blokade kapal-kapal nelayan negara sekitar yang masuk perairan LCS (Lunn, 2016).

Kebijakan agresif China di LCS berimbas kepada keterlibatan AS sebagai kekuatan luar yang sangat berkepentingan dengan LCS. Dalam hal ini, apa yang dikhawatirkan AS adalah langkah China dinilai mengancam "kepentingan nasional" AS di LCS. Seiring dengan pesatnya kemajuan pembangunan, China tentunya sangat berambisi untuk mempekuat postur pertahanannya. LCS dipandang China sebagai basis pertahanan yang sangat vital dalam menopang stabilitas politik kawasan dan dalam negeri. Pada prinsipnya China mempunyai tiga tujuan utama di LCS khususnya dan Asia Tenggara umumnya. (1) untuk merealisasikan integrasi kawasan, (2) untuk mengontrol sumber daya alam, dan (3) untuk kepentingan strategi pertahanan (Dutton, 2011).

Situasi demikian menjadikan LCS mempunyai potensi konflik yang sangat tinggi. Sebuah survei menunjukkan bahwa tingginya potensi konflik tersebut dipengaruhi beberapa faktor. Indikator bahaya konflik di LCS atau disebut sebagai tactical warning signals menunjukkan bahwa memanasnya politik di LCS ditandai oleh beberapa skenario misalnya meningkatnya latihan militer untuk "memperingatkan" negara lain, saling memberi peringatan bahaya antar diplomat/militer, saling memprovokasi, saling mengintimidasi dan meningkatnya pergerakan kapal perang di kawasan tersebut (Glaser, 2012).

Dalam situasi yang demikian, diskursus konflik LCS tampaknya lebih didominasi rivalitas China dan AS di kawasan Asia Tenggara. Sebagaimana perang proxy layaknya Perang Dingin, kedua negara besar tersebut juga mempunyai sekutu dan penyeimbang dengan bentuk yang agak berbeda. Misalnya Vietnam yang sebelumnya sekutu China menjadi semakin konfrontatif terhadap China. Demikian juga, eksistensi ASEAN ternyata memainkan peran menarik untuk dicermati. Bagi China, hubungan harmonis dengan ASEAN mutlak diperlukan untuk menjaga 
kepentingan China di LCS. Meskipun sebagian besar anggota ASEAN sangat menolak agresifitas China di LCS, namun bagi Kamboja langkah China harus didukung. Misalnya, dalam agenda ASEAN Summit 2012 di Phnom Penh, Kamboja dengan sengaja menganulir agenda pembahasan LCS sehingga secara tidak langsung menguntungkan China. Faktanya, langkah Kamboja tidak lain karena China merupakan negara donor dan investor terbesar Kamboja (Kim, 2015).

Konflik LCS ternyata juga berdampak pada meningkatnya persaingan persenjataan dan kemampuan pertahanan negara-negara terlibat dari segi kekuatan jumlah pasukan. Dalam grafik berikut dapat dilihat pemetaan kemampuan militer negara-negara yang terlibat di LCS. Selain itu, Tabel 1. berikut juga memuat beberapa negara yang sangat mungkin terlibat konflik akibat eskalasi konflik LCS yang sangat tinggi.

Informasi pada Tabel 1. menunjukkan jumlah pasukan yang terbagi dalam tiga angkatan yaitu angkatan darat, angkatan laut dan angkatan udara. Tiga negara yaitu China, India dan Korea Utara mempunyai kekuatan darat mencapai 1 juta personel. Negara lain yang juga mempunyai kekuatan darat cukup besar di kawasan Asia Tenggara adalah Vietnam (412.000 personel) diikuti oleh Myanmar (375.000) dan Indonesia (300.400 personel). Aspek pertahanan udara, China terlihat paling dominan dengan jumlah prajurit angkatan udara mencapai 398.000 melebihi personel angkatan lautnya yang hanya 235.000 (The Asia Maritime Transparency Initiative and The Center for Strategic and International Studies, 2014).

Tabel 1. Kekuatan Militer Negara-Negara di Sekitar Laut China Selatan

\begin{tabular}{l|l|l|l|l}
\hline No. & Negara & $\begin{array}{l}\text { Angkatan } \\
\text { Darat }\end{array}$ & $\begin{array}{l}\text { Angkatan } \\
\text { Laut }\end{array}$ & $\begin{array}{l}\text { Angkatan } \\
\text { Udara }\end{array}$ \\
\hline 1. & Australia & 28.600 & 13.550 & 14.050 \\
\hline 2. & Brunei Darussalam & 4.900 & 1.000 & 1.100 \\
\hline 3. & Filipina & 86.000 & 24.000 & 15.000 \\
\hline 4. & India & 1.129 .900 & 58.350 & 127.200 \\
\hline 5. & Indonesia & 300.400 & 65.000 & 30.100 \\
\hline 6. & Jepang & 151.050 & 45.500 & 47.100 \\
\hline 7. & Kamboja & 124.300 & 2.800 & 1.500 \\
\hline 8. & Korea Selatan & 522.000 & 68.000 & 65.000 \\
\hline 9. & Korea Utara & 1.020 .000 & 60.000 & 110.000 \\
\hline 10. & Myanmar & 375.000 & 16.000 & 15.000 \\
\hline 1. & Malaysia & 80.000 & 14.000 & 15.000 \\
\hline 12. & Singapura & 50.000 & 9.000 & 13.500 \\
\hline
\end{tabular}




\begin{tabular}{l|l|l|l|l}
\hline 13. & Taiwan & 200.000 & 45.000 & 45.000 \\
\hline 14. & Thailand & 245.000 & 69.850 & 46.000 \\
\hline 15. & Vietnam & 412.000 & 16.900 & 30.000 \\
\hline
\end{tabular}

Sumber: The Asia Maritime Transparency Initiative and The Center for Strategic and International Studies (2014)

Pada level berikutnya, muncul beberapa insiden ketegangan antar negaranegara yang terlibat di LCS. Sejak tahun 1956 tercatat ada 80 peristiwa ketegangan yang melibatkan berbagai pihak di LCS. Pada 6 Juni 1956 misalnya Taiwan adalah menjadi negara pertama yang menempatkan pasukannya secara permanen di LCS tepatnya di Pulau Itu Aba. Setelah sekian lama baru muncul peristiwa kedua yang terjadi tahun 1970. Kali ini giliran Filipina yang secara sepihak mengklaim lima bagian di wilayah barat Kepulauan Spratly. Tindakan Filipina juga diikuti Vietnam Selatan yang mengklaim enam bagian di wilayah tersebut dan memasukkannya sebagai wilayah teritorialnya pada tahun 1974. Akibatnya, pecah insiden "Battle of the Paracel Islands" yang melibatkan China dan Vietnam Selatan. Sekitar 36 personel kedua negara tewas dalam kontak senjata dan masih banyak lagi peristiwa ketegangan di LCS dalam beberapa dekade belakangan. Seiring dengan agresifitas China dengan kemampuan ekonomi dan militer yang semakin meningkat, 60\% lebih insiden ketegangan di LCS baru terjadi tahun 2000 ke atas(Center for a New American Security, 2016). Perkembangan terbaru, China semakin agresif membangun sejumlah infrastruktur militer di LCS seperti pelabuhan, landasan pacu pesawat tempur terutama di Kepulauan Spratly (The New York Times, 27/10/2015). Situasi tersebut pada akhirnya memicu ketegangan dan konflik di LCS.

Pada waktu yang sama, China sangat sukses memanfaatkan "kelemahan" diplomasi antar negara Asia Tenggara yang tergabung dalam ASEAN dengan politik "pecah-belah." Salah satu "kelemahan" tersebut adalah lemahnya diplomasi kolektif atau ASEAN's weak multilateral approach.Dalam hal ini China juga sangat sukses memanfaatkan ASEAN Regional Forum (ARF)yang juga melibatkan AS untuk kepentingan diplomasi China terkait isu LCS. Dampaknya hubungan China-ASJepang-India dan lain-lain juga semakin kompleks (Jones \& Smith, 2015). Terlibatnya AS dan negara-negara besar menunjukkan LCS mempunyai arti penting dan strategis bagi negara tersebut.Dengan kata lain, kompleksitas dan perdebatan LCS tampak 
mengesampingkan isu hukum laut internasional. Sebaliknya, isu konflik politik antar kekuatan-kekuatan yang berkepentingan di LCS dan bagian dari percaturan kekuasaan terlihat lebih menonjol (Shi, 2015). Artinya, konflik LCS tidak lepas dari perebutan pengaruh dan kuasa serta kepentingan internasional terutama negara besar terutama China dan AS.

\section{Kesimpulan}

Dengan demikian, konsep regionalisme dan kompleksitas LCS mempunyai sebuah kesimpulan bahwa konflik LCS memunculkan sebuah tantangan baru bagi bangunan regionalisme Asia Tenggara. Hal ini tidak lain disebabkan oleh adanya "benturan" kultur diplomasi antara ASEAN dengan China. ASEAN yang menganut "ASEAN Way" jelas memegang teguh prinsip non-intervensi dan konsensus. Namun, keadaan ini justru dimanfaatkan China yang secara diam-diam melakukan upaya diplomasi langsung kepada negara-negara terkait. Akibatnya, segala bentuk konsekuensi bilateral antara negara ASEAN-China tidak bisa diganggu gugat oleh anggota lain karena adanya "ASEAN Way" tersebut. Sehingga, dalam konteks LCS regionalisme Asia Tenggara yang tercermin dalam ASEAN tidak bisa berbuat banyak karena "hambatan" norma tersebut. Pada akhirnya, China melalui ARF berhasil memanfaatkan "lemahnya" regionalisme ASEAN untuk kepentingan nasionalnya. Walaupun demikian, upaya-upaya ASEAN untuk menjaga stabilitas dan perdamaian Asia Tenggara harus diapresiasi tinggi. Oleh karena itu, tantangan menjaga stabilitas politik inilah yang menjadi tantangan besar ASEAN sebagai organisasi regional salah satu yang berpengaruh di dunia.

\section{Daftar Rujukan}

\section{Buku}

Duffield, J. S., Michota, C., \& Miller, S. A. (2008). Alliance. In Paul D. William (Ed.), Security Studies. London and New York: Routledge.

Karim, A. (2013). Moving Forward with ASEAN Connectivity: Cooperation, Opportunity and Challenges in Malaysia-Thailand/Vietnam Relations. In Azhari Karim, James Campbell \& Sharan Srinivas (Eds.), Repositioning Malaysian Foreign Policy (pp. 93-106). Penang: Universiti Sains Malaysia 
Johnston, A. I. (2003). Socialization in International Institutions: The ASEAN Way and International Relations Theory. In G. John Ikenberry \& Michael Mastanduno (Eds.), International Relations Theory and the Asia Pacific (pp. 107162). New York: Columbia University Press.

Solongen, E. (2010). Multilateralism, Regionalism, and Bilateralism: Conceptual Overview from International Relations Theory. In N. Ganesan \& Ramses Amer (Eds.), International Relations in Southeast Asia: Between Bilateralism and Multilateralism. Singapore: Institute of Southeast Asian Studies.

Weiss, M. (2010). Malaysia-Indonesia Bilateral Relations: Sibling Rivals in a Fraught Family. In N. Ganesan \& Ramses Amer (Eds.), International Relations in Southeast Asia: Between Bilateralism and Multilateralism (pp. 171-198). Singapore: Institute of Southeast Asian Studies.

Weatherbee, D. (2009). International relations in Southeast Asia: the struggle for autonomy. Lanham, Maryland: Rowman \& Littlefield Publishers, Inc.

\section{Artikel}

Acharya, A. (1998). Culture, security, multilateralism: The 'ASEAN way' and regional order. Contemporary Security Policy, 19(1), 55-84.

Anwar, D. F. (1996). Regionalism versus Globalism: A Southeast Asian Perspective. Korean Journal of Defense Analysis, 8(2), 29-52.

Dutton, P. (2011). Three Disputes and Three Objectives: China and the South China Sea. Naval War College Review, 64(4), 42-67.

Jones, D. M. \& Smith, M.L.R. (2015). Can Asean ever solve the South China Seas dispute through multilateral dialogue? Telegraph 24/11/2015.

Kim, J. (2015). Territorial Disputes in the South China Sea: Implications for Security in Asia and Beyond. Strategic Studies Quarterly, 107-141.

Mauzy, D. K., \& Job, B. L. (2007). U.S. Policy in Southeast Asia: Limited Reengagement after Years of Benign Neglect. Asian Survey, 47(2), 622-641.

Roy, D. (2005). Southeast Asia and China: Balancing or Bandwagoning? Contemporary Southeast Asia, 27(2), 305-322.

Salleh, A. (2007). Dispute Resolution through Third Party Mediation: Malaysia and Indonesia. Intellectual Discourse, 15(2), 147-165. 
Salleh, A., Che M. R., Che H., \& Jusoff, K. (2009). Malaysia's policy towards its 1963 - 2008 territorial disputes. Journal of Law and Conflict Resolution 1(15), 107116.

Walt, S. M. (1985). Alliance Formation and the Balance of Power. International Security, 9(4), 3-43.

\section{Working Paper Series/Reports}

Bateman, S. (2011) Managing the South China Sea: Sovereignty is not the Issue. RSIS Commentaries No. 136/2011 dated 29 September 2011. Singapore S.Rajaratnam School of International Studies, NTU.

Boston Global Forum. (2015) Recent Trends in the South China Sea Disputes.

Center for a New American Security. (2016). Timeline: 1955-Present. Washington, DC: Center for a New American Security.

Council on Foreign Relations. (2016). Territorial Disputes in the South China Sea

Emmers, R. (2005) Maritime Disputes in the South China Sea: Strategic and Diplomatic Status Quo. Working Paper No. 87. Singapore: The Institute of Defence and Strategic Studies (IDSS), Nanyang Technological University.

Gewirtz, P. (2016) Limits of Law in the South China Sea. East Asia Policy Paper 8 May 2016. Washington, D.C.: The Brookings Institution.

Glaser, B. S. (2012) Armed Clash in the South China Sea. Contingency Planning Memorandum

No. 14. Washington DC.: Council on Foreign Relations Press.

Gupta, S. (2015) The Nine Dash Line and Its Basis in International Law. China-US Focus.

Hong Kong: China-United States Exchange Foundation.

Kung, P. (2015) The South China Sea Disputes: Three Years After Cambodia. RSIS Commentaries No. 042 - 2 March 2015. Singapore: S.Rajaratnam School of International Studies, NTU.

Lunn, J. (2016) The South China Sea dispute: January 2016 update. Briefing Paper No. 7481, 28 January 2016. London: House of Commons Library.

Maritime Security Programme Conference Report. (2007). The South China Sea: Towards A Cooperative Management Regime 16 - 17 May 2007. Singapore: Maritime Security Programme, S. Rajaratnam School of International Studies, Nanyang Technological University. 
Poling, G. B. (2013) The South China Sea in Focus: Clarifying the Limits of Maritime Dispute.

A Report of the CSIS Sumitro Chair for Southeast Asian Studies July 2013. Lanham, MD: Rowman \& Littefield.

Presidential Decree no. 1596. (1978). Declaring Certain Area Part of the Pbilippine Territory and Providing for their Government and Administration - 11 June 1978. Manila: The Government of the Republic of the Philippines.

Roach, J. A. (2014) Malaysia and Brunei: An Analysis of their Claims in the South China Sea. CNA Occasional Paper August 2014. Arlington, VA: The CNA Corporation.

Shi, X. (2015) UNCLOS and China's Claim in the South China Sea. Indo-Pacific Strategic Papers. Canberra: The Centre for Defence and Strategic Studies (CDSS), Australian Defence College.

The Asia Maritime Transparency Initiative and The Center for Strategic and International Studies. (2014). Atlas- South China Sea dalam bttp:// amti.csis.org/atlas/ (diakses 21 Juni 2016).

Tonnesson, S. (2001) An International History of the Dispute in the South China Sea. EAI Working Paper No. 71. Singapore East Asian Institute, National University of Singapore.

U.S. Energy Information Administration. (2013). South China Sea

Vu, T. M. \& Phuong, N. T. (2014) South China Sea: Promise and Problems of COC. RSIS Commentaries No. 163 - 13 August 2014. Singapore S.Rajaratnam School of International Studies, NTU.

Yujuico, E. (2015) The real story behind the South China Sea dispute. Situation Analysis. London: London School of Economics and Political Science.

\section{Prosiding Konferensi}

Fravel, T. M. (2012). The US and China in Regional Security: Implication for Asia and Europe Paper presented at the Berlin Conference on Asian Security 2012, Berlin.

Santos, S. C. (2008). Constructivism and Regional Integration Theories. The Application to Mercosur. Paper presented at the The Second WISC Conference, Faculty of Social Sciences, University of Ljubljana, Ljubljana, Slovenia. 


\section{Majalah/Surat Kabar}

Muzaffar, C. (2012). How to Resolve Conflicts in the South China Sea Al-Jazeera English 4 July 2012.

The New York Times. (27/10/2015). What China Has Been Building in the South China Sea.

Voice of America. (8/5/2015). Images Show Vietnam's S. China Sea Reclamation as China Defends Own

\section{Thesis}

Ma, S. (2006). China's Multilateralism and the South China Sea Conflict: Quest for Hegemonic Stability? (Master Thesis), National University of Singapore, Singapore. 